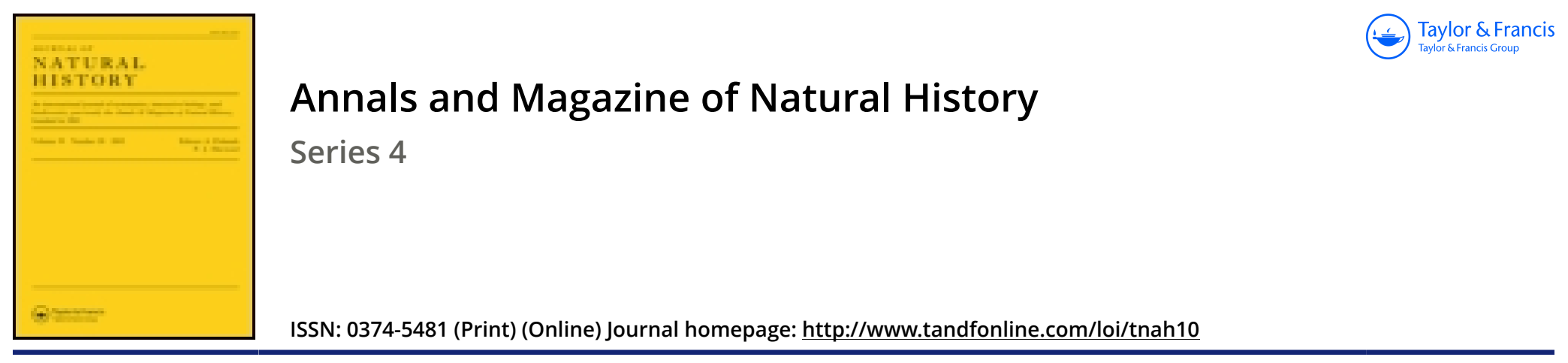

\title{
IX.- On a small collection of Orthopterous insects of the Families Phasmidæ and Mantidæ from Australia and New Britain, with descriptions of four new species
}

\section{Prof. J. Wood-Mason}

To cite this article: Prof. J. Wood-Mason (1877) IX.-OOn a small collection of Orthopterous insects of the Families Phasmidæ and Mantidæ from Australia and New Britain, with descriptions of four new species, Annals and Magazine of Natural History, 20:115, 74-77, DOI: 10.1080/00222937708682195

To link to this article: http://dx.doi.org/10.1080/00222937708682195

$$
\text { 曲 Published online: } 13 \text { Oct } 2009 .
$$

Submit your article to this journal ए

\section{山ll Article views: 3}

View related articles ¿ 
IX.-On a small Collection of Orthopterous Insects of the Families Phasmidæ and Mantidæ from Australia and New Britain, with Descriptions of four new Species. By Prof. J. Wood-Mason, Deputy Superintendent, Indian Museum, Calcutta.

THE insects described in the following pages have all been recently received by me from my valued correspondent $\mathrm{Mr}$. Charles French, of the Royal Botanic Gardens, Melbourne, South Australia, who is responsible for the correctness of the localities here given.

The occurrence in New Britain of near allies of two species from the Fiji Islands is of particular interest.

\section{Family Phasmidæ.}

\section{Bacteria Frenchi, n. sp.}

q. Slender, cylindrical, uniform dark brown. Head slightly narrowed from before backwards, and armed right between the eyes with a pair of minute spines. A most distinct raised median dorsal line runs along the whole length of the body. Mesonotum and metanotum granulated, some of the granules being developed into minute spines, especially on the former. Both divisions of the metanotum and the dorsal arcs of the five basal segments of the abdomen each with a small rounded lobe at the hinder extremity. Abdomen above sparingly obsoletely granulated, and with three smooth longitudinal ridges on each side of the middle line on all the segments except the last two, on to which the three median ones only are continued, and gradually attenuated from the base of its fifth segment to its extremity; two terminal segments strongly carinate, especially the last, which is acute-angled at the extremity ; sixth ventral segment with an obtuse rounded process at its hinder end. The operculum, which is longitudinally but slightly convex, rounded at the free end, and carinate along its apical half, reaches only to about the middle of the last dorsal segment. Cerci minute, invisible from above. Legs simple; first joint of the tarsus in all rather longer than the rest taken together.

Total length 2 inches 5 lines; antennæ 9.75 lines; head 1.25 line; prothorax 1 line; mesothorax 6.25 lines; metathorax 4 lines; abdomen $13+3 \cdot 5=16.5$ lines; fore femur 7 lines, tibia $7 \cdot 5$; intermediate femur 6 lines, tibia $7 \cdot 5$; posterior femur $7 \cdot 5$ lines, tibia 9 ; breadth about 1 line.

$H a b$. North Australia (C. French). A single specimen, preserved in alcohol. 
The insect (B. tenuis, Hope, MS.) figured by Westwood, on pl. xxvii. fig. 2 of his monograph, as the male of $B$. coenosa is possibly the opposite sex of this species, slight indications of lobes at the ends of the segments of the abdomen being to be seen in Westwood's figure.

\section{Phibalosoma nove-britannia, $\mathrm{n}$. sp.}

q. Closely allied to $P$. pythonius and to $P$. apollonius, both from the Fiji Islands. It has the spiny thorax of the latter, and the abdomen of the former. It differs from $P$. pythonius not only in its spiny thorax and shorter antennæ, but also in the form of the fifth, sixth, and seventh dorsal segments of the abdomen, which gradually widen from the base to the apex, so that the abdomen has in this part conspicuously serrated margins; and from $P$. apollonius not only in the form of the abdomen, but apparently also in its almost completely triquetrous four posterior thighs and tibia, all of which have a row of sharp spines along the middle of the under surface, and in having the first joint of all the tarsi longer and slenderer. The mesosternum has two parallel rows of spines along the middle, of which no mention is made by Westwood in his description of the latter. The fore legs are unfortunately wanting.

Total length 8.5 inches; antennæ 24.5 lines; head 6.5 lines ; prothorax 4.5 lines; mesothorax 20.5 lines; metathorax 12.5 lines; abdomen 4 inches 3 lines +9 lines + operculum 7 lines $=5$ inches 7 lines; intermediate femur 20, tibia 20, tarsus 9.75 lines ; posterior femur 22, tibia 24, tarsus 11 lines.

Hab. New Britain (C. French). A single specimen, preserved in alcohol.

\section{Phyllium novce-britannioe, n. sp.}

+ . Closely allied to $P$. lobiventre from the Fiji Islands, which it resembles in the form and ornamentation of the mesonotum, in the granulation of the head, legs, and margins of the segments of the body, in the structure of the legs and tegmina, and, finally, in size, but from which it differs in the rudimentary condition of the lobe on the inner side of the fore tibir, and, conspicuously, in the form of the abdomen; this widens gradually to the middle of the third segment, whence its sides converge slightly and gradually to the middle of the sixth segment, which curves inwards to the base of the seventh, this with the last two forming a triangular mass with slightly hollow sides.

Total length 2 inches 4.5 lines; head 2.75 lines; prothorax 
$2 \cdot 25$ lines; mesothorax 2 lines; abdomen $13 \cdot 5+4 \cdot 75=18 \cdot 25$ lines; breadth of abdomen at base $5 \cdot 25$, at angulation of third segment $13 \cdot 5$, at junction of fifth and sixth 11 , at junction of sixth and seventh $7 \cdot 5$ lines; length of tegmina $18 \cdot 5$, breadth of tegmina $7 \cdot 25$ lines.

Hab. New Britain (C. French). A single gravid female, preserved in alcohol.

\section{Family Mantidæ.}

Subfamily HysteromantiNa.

4. Orthodera prasina, Burmeister.

Orthodera prasina, Burmeister, Handb. d. Entom. Band ii. 2te Abtheil. S. 529 (1838).

Mantis rubrocoxata, Serville, Hist. Nat. des Ins. Orthoptères, p. 203, 오 (1839).

Mantis Hobsonii, Le Guillou, Rev. Zool. Soc. Cuv. t. iv. p. 293 (1841).

Bolidena Hobsonii, Blanchard, Voy. de l'Astrolabe et la Zélée, Zool. t. iv. p. 356 , pl. i. fig. 7 , $\&$ (1853).

Hab. A single female, preserved in alcohol, from North Australia (C. French).

\section{Orthodera marginata, Saussure.}

Orthodera marginata, Saussure, Mélanges Orthopt. $4^{e}$ fasc. p. 8, pl. 8 . fig. 1, 우 (1872).

$H a b$. A single specimen of the female, preserved in alcohol, from North Australia (C. French).

\section{Archimantis armatus, n. sp.}

․ Robust. Prothorax with its lamellar lateral margins coarsely toothed from end to end; under surface of neck covered with coarse spiniform tnbercles, one of which, larger than most of the rest, is placed immediately in front of the insertion of each fore leg. Organs of flight reaching a little beyond the extremity of the second segment of the abdomen: tegmina opaque throughout, except along the sutural margin and the anal area, which are hyaline; the stigma has a black-brown spot at either end : wings with the marginal area alone opaque, the rest perfectly hyaline. Terminal joint of cerci broadly rounded off at the extremity, not pointed. Anterior coxa furnished with 6-8 blunt spines, between some of which are one or two smaller ones; tibia with 17 teeth on the inner and 11-13 on the outer edge.

Total length 104 millims.; prothorax $37 \cdot 5$, of which the 
neck is 10 ; width of prothorax at supracoxal dilatation $7 \cdot 33$; height of head 7 , breadth of head $10^{\circ} 5$; length of mesonotum and metanotum taken together 18.5 , of abdomen 47.5 , of cerci 12 , breadth of cerci 1.33 ; length of fore coxa 20 , femur 24 , tibia (straight portion) 10, first tarsal joint 8 ; length of intermediate femur 24 , tibia 24 , first tarsal joint 5.5 ; length of posterior femur 30 , tibia 34 , first tarsal joint 9 ; length of tegmina 33 , of stigma 6 , breadth of tegmina 10 .

Hab. A single specimen; preserved in alcohol, from North Australia (C. French).

\section{Tenodera australasia, Leach.}

Mantis australasie, Leach, Znol. Miscellany, p. 78, tab. xxiv.

Hab. North Australia (C. French). A single specimen, in alcohol.

\section{Subfamily Proteronantina.}

8. Phthersigena Kraussii, Saussure.

Haania Kraussii, Saussure, Mél. Orthopt. $4^{\circ}$ fasc. p. 75, pl. 8. fig. 26.

$H a b$. Two adult and two immature females from North Australia (C. French).

Calcutta, May 4, 1877.

\section{X.-On Ovulites margaritula.}

By Professors W. K. Parker and T. R. Jones.

In the 'Ann. \& Mag. Nat. Hist.' for April 1860, ser. 3, vol. v. pp. 292, 293, we described the little egg-shaped and pearl-like Foraminifer, named Ovulites margaritula by Lamarck, and its elongate varieties. At that time we referred it to the hyaline group of Foraminifera; but we have lately discovered that it belongs to a different series. Some specimens in particular are beautifully smooth, polished, and subtranslucent, like the most delicate of the Peneroplides; and we mistook this for the "clear, smooth, glassy appearance" belonging to the hyaline Foraminifers. Far more usually the specimens are quite opaque and porcellaneous; and this appearance we wrongly referred to fossilization.

Whether ovoid, clavate, or cylindrical, Ovulites is really one of the Dactyloporidæ. D'Orbigny placed Ovulites next to Dactylopora among his Monostegin (in 1851), but these comprise some very heterogenous kinds.

The apertures with which the shell-wall of Ovulites is per- 